\title{
Polycentricity: \\ not a Panacea, but a Piece of the Puzzle
}

\author{
POR Fronika de Wit* \\ * Institute of Social Science, University of Lisbon, Portugal
}

Jordan, A., Huitema, D., van Asselt, H. \& Forster, J. (2018). Governing Climate Change: Polycentricity in Action? Cambridge: Cambridge University Press

The 2015 Paris Agreement highlighted a transition in the climate governance landscape, from top-down to more bottom-up mechanisms, recognizing the importance of the engagement of all levels of government and various actors. Before Paris, the international climate regime - centred around the 1992 United Nations Framework Convention on Climate Change (UNFCCC) - had shown little to no results in effectively dealing with climate change. Critically reflecting upon the gridlocked climate governance regime, the late Nobel Prize winner Elinor Ostrom was the first to point to emerging polycentric systems for coping with climate change. A polycentric system - in contrast with the monocentric UNFCCC or state-led governance systems - is characterized by multiple governing authorities (e.g. subnational governments, networks of governments, companies) that have considerable independence to make norms and rules in relation to climate change. Ostrom (2010) warned that polycentric systems are not a panacea, but added that "there are no panaceas (...) for complex problems such as global warming" (p. 555). She underlined the need to critically study the strengths and weaknesses of polycentric climate governance. Although research on climate governance is rapidly increasing, nobody took up Ostrom's vision of a holistic research programme that applies the assumptions of polycentric governance to the climate change challenge. Until May 2018, when the book Governing Climate Change: Polycentricity in Action?, published by Cambridge University Press and edited by Andrew Jordan, Dave Huitema, Harro van Asselt and Johanna Forster, made an attempt to assess the ability of polycentric theory to address the global challenge of climate change. 
The open access book, bringing together contributions from over 40 experts in the field of climate governance, can be seen as one of the main outputs of a large international project (INOGOV - Innovations in Climate Governance: www.inogov.eu) funded by the European Cooperation in Science and Technology (COST) and coordinated by the Tyndall Centre for Climate Change Research of the University of East Anglia. The book's main aim is to explore what is to be gained by thinking about climate governance as an evolving polycentric system, and, in order to do this, it uses three different perspectives: 1) a descriptive perspective: it looks at what a polycentric perspective adds to the discussion on climate governance in general; 2) an explanatory perspective: challenging the more top-down perspective of traditional climate governance, it looks at what it means to have polycentric governance and at the implications for matters such as authority and power, accountability, legitimacy and innovativeness; and 3) a normative perspective: a source of prescriptions on how to improve polycentric climate governance.

Governing Climate Change: Polycentricity in Action? is divided into five parts. Part 1 (Chapter 1) provides the context of the book and highlights the absence of a single summary of the essential features of polycentric climate governance in the literature. Actually, by introducing the term 'polycentric' to the climate governance arena, Ostrom was able to unify the highly dispersed field and the diverse terminology used until so far, ranging from regime complexity, multi-level governance, fragmentation to hybrid governance. In an attempt to summarize the essential features of polycentric climate governance, the book provides the following five core propositions: 1) Local action: governance initiatives are likely to take off at a local level through processes of self-organization; 2) Mutual adjustment: governing units spontaneously collaborate; 3) Experimentation: experimentation facilities innovation and learning. 4) Trust: trust builds up quicker when units self-organize; and 5) Overarching rules: local initiatives work best when there are overarching rules.

The second part of the book (Chapters 2-5) deals with specific actors and domains of climate governance, namely: international governance, national governance, transnational governance, and city and subnational governance. Each actor is discussed by different experts in separate chapters, in which they apply the book's five core propositions to the actor in question and reflect on the relationship within and between different domains. The overview of the climate governance actors highlights how they are both competing and cooperating, interacting and learning from one another. Part 3 of the book (Chapters 6-12) looks at governance processes and aims to answer the question how polycentric systems function. This part, which reflects on the validity of the five core propositions, can be divided into processes of initiating (Chapters 7 and 8), processes of connecting (Chapters 9, 10 and 11) and processes of learning (Chapters 6 and 12). Part 4 of the book (Chapters 13-19) examines substantive governance challenges and looks at the implications of polycentric governance for climate change and system-wide functions. These are on the one hand emerging challenges, such as the global carbon market (Chapter 13), decarbonisation (Chapter 
14), technology (Chapter 15), experimentation (Chapter 16) and adaptation to climate change (Chapter 17) and on the other hand longstanding challenges, such as climate justice (Chapter 18) and legitimacy and accountability (Chapter 19).

The fifth and last part of the book (Chapter 20) is left for synthesis and concluding reflections on the promises and limits of a polycentric approach to describe, explain and prescribe transitions in climate governance. First, as a descriptive device, the polycentric approach offers a more holistic perspective of the climate governance landscape and its interactions. Secondly, from the explanatory perspective, the breath and openness of the polycentric approach make it suitable for complex, empirical and interdisciplinary challenges, such as climate change. Like the authors state: "...polycentric governance provides a means to assemble the jigsaw pieces into a more complete picture" (p. 378). The authors mention two explanatory challenges that require further research: 1) the role of the state in polycentric governance, and the balance between monocentric and polycentric forces; and 2) the temporal dynamics of polycentric governing: how long does it take to form and how and why does it change? Lastly, on the normative implications of polycentricity for climate governance, the authors remind us that Elinor Ostrom always counselled against the 'panacea' thinking. Also, academics are probably not the best people to provide prescriptions, as they are still 'playing catch-up' (p. 380) with the practitioners in the field.

On the positive side, Governing Climate Change: Polycentricity in Action? provides a holistic, systems-thinking approach to deal with the climate change challenge: a complex system with many interactions. Also, the literature on climate governance is very fragmented both disciplinarily (political science, economics, geography, environmental science, sociology) and empirically (transnational, national, local). By bringing together experts from different disciplinary backgrounds, this book offers a more transdisciplinary perspective and connects diverse research institutions. Finally, the polycentric scholars from the Ostrom-school (known as the Ostrom Workshop) are very passionate and engaged in addressing real-world problems and bringing science and policy closer together. However, they are not always as critical as academics should be. That is why the authors of the book clearly state that they are not taking polycentricity for granted. By placing a question-mark in the title of book - Polycentricity in Action? - they question the approach and are not presenting it as the perfect solution to the problem of climate change.

On the critical side, although the book states there is no uniform definition for polycentric climate governance, it is not clear what exactly we are looking at. Is it polycentric governance as a concept, a theory, or a normative idea? The descriptive, explanatory and normative perspective are mixed through the chapters. After reading, it is still impossible to clearly describe, explain or prescribe what polycentric climate governance is, as it is used with different levels of precision and different conceptualizations of its vertical and horizontal forms of differentiation. The authors state that polycentric governance: "offers a distinctly different take on contemporary 
climate governance" (p. 20) and that it "goes beyond labels such as 'fragmented', or 'multilevel' or 'complex"' (p. 377), but by trying to transcend existing debates and categorizations, the book fails to provide a clear conceptualization of polycentric climate governance and how it differs from other types of governance, such as earth system governance or resilience governance.

Another critical remark in relation to the book is on issues of justice and equity, which are deeply rooted in climate governance and interwoven with particular power distributions. However, the issue of power is still rather neglected by the concept of polycentricity and not sufficiently addressed in the book. Nevertheless, asking the question of who has power in climate governance seems to be decisive for both, satisfying analyses of climate governance as well as probable political recommendations. Hence, power as a decisive factor should be further accounted for in future research projects. Lastly, the book claims to bring together some of the world's leading experts on climate governance and look at the global challenge of climate change, but both the authors and content of the chapters are predominantly Eurocentric. The book lacks contributions from the global south and the link between climate governance and the debate on development versus conservation.

However, all in all Governing Climate Change: Polycentricity in Action? is a mustread for anyone interested in either the field of governance or climate change. It might not be as encompassing as Elinor Ostrom had hoped it to be, but it provides a helpful way of system-thinking in a world with increasing uncertainty and complexity.

\section{References}

Jordan, A., Huitema, D., van Asselt, H. \& Forster, J. (2018). Governing Climate Change: Polycentricity in Action? Cambridge: Cambridge University Press.

Ostrom, E. (2010). Polycentric systems for coping with collective action and global environmental change. Global Environmental Change, 20(4), 550-557. 